\title{
Ductal Eccrine Carcinoma with Abundant
} Fibromyxoid Stroma

National Cancer Institute

\section{Source}

National Cancer Institute. Ductal Eccrine Carcinoma with Abundant Fibromyxoid Stroma.

NCl Thesaurus. Code C43349.

A variant of ductal eccrine carcinoma with abundant fibromyxoid stroma. 